\title{
EVOLUTION OF NUTRIENTS AND SOIL CHEMICAL PROPERTIES OF SEVEN ORGANIC FERTILIZERS IN TWO CONTRASTING SOILS UNDER CONTROLLED CONDITIONS
}

\author{
Juan Hirzel ${ }^{1 *}$, Denise Donnay², Claudio Fernández ${ }^{3}$, Sebastián Meier ${ }^{4}$, Octavio Lagos ${ }^{5}$, Patricio \\ Mejias-Barrera ${ }^{6}$, and Francisco Rodríguez ${ }^{7}$
}

${ }^{1}$ Instituto de Investigaciones Agropecuarias, INIA Quilamapu, Av. Vicente Méndez 515, Chillán, Chile. ${ }^{2}$ Hortifrut S.A., Avenida del Cóndor 600, Huechuraba, Santiago, Chile.

${ }^{3}$ Universidad de Concepción, Facultad de Agronomía, Av. Vicente Méndez 595, Chillán, Chile.

${ }^{4}$ Instituto de Investigaciones Agropecuarias, INIA Carillanca, camino Cajón Vilcún km 10, Temuco, Chile.

${ }^{5}$ Universidad de Concepción, Facultad de Ingeniería Agrícola, Av. Vicente Méndez 595, Chillán, Chile.

${ }^{6}$ Instituto de Investigaciones Agropecuarias, INIA Remehue, Ruta 5 Norte km 8, Osorno, Chile.

${ }^{7}$ Universidad del BíoBío, Departamento Ciencias de la Educación, Facultad de Educación y Humanidades, Universidad del BíoBío, Chillán, Chile.

*Corresponding author E-mail: jhirzel@inia.cl

\begin{abstract}
Organic food production has increased the demand for organic supplies in agriculture. Organic fertilizers are known to have an effect on crop and soil properties, but this effect has been little studied. This research evaluated the effect of seven nitrogen fertilizers allowed for use in organic production and one conventional fertilization treatment adjusted to a similar dose of total nitrogen (N), on chemical properties of two soils of contrasting physicochemical properties (sandy loam Mollisol and silty loam Andisol) incubated under aerobic conditions and controlled 6 times over 112 d. Treatments were: Compost (CO), Fertil (F), Purely Grow (PG), Purely Lysine (PL), Blood meal (BM), Lupine meal (LM), Sodium nitrate (SN), conventional fertilization (CF), and a control without fertilization (CT). The experiment was conducted in a split-plot design for each soil. The results showed that the fertilizers affected soil $\mathrm{pH}$, salinity (electrical conductivity, EC), and the concentrations of phosphorus (P), potassium (K), calcium (Ca), magnesium (Mg) and sulfur (S). In general, the highest values of $\mathrm{pH}$, available $\mathrm{P}$, and exchangeable $\mathrm{K}, \mathrm{Ca}$ and $\mathrm{Mg}$ were obtained using $\mathrm{CO}$ in both soils, whereas PL reported the lowest values for most parameters evaluated. The evolution of each parameter over time showed interactions with the fertilization treatment, with a steady decrease in $\mathrm{pH}$ and an increase in EC in both soils. Differences in the average values of chemical properties during incubation with respect to their initial values were related to the physicochemical and organic characteristics of each soil.
\end{abstract}

Key words: Nitrogen, organic fertilizers, soil physical-chemical properties, sulfur, nutrient dynamic, phosphorus, ash volcanic, sandy loam.

Received: 16 April 2018. Accepted: 11 June 2018 


\section{INTRODUCTION}

Organic production has significantly increased worldwide mainly because of the nutritional quality and safety of organic food, the positive effects on the environment, and economical profits for the farmer (Wang et al., 2008; Karanatsidis and Berova, 2009; Epule et al., 2015). Compared to conventional production, organic farming does not have a large number of tools for controlling pathogens or weeds, while fertilization sources are also limited. In this sense, one of the major concerns in organic farming (for both annual and perennial crops) is nitrogen supply as this is closely related to crop productivity (Miller et al., 2006).

Nitrogen organic fertilizers include: compost, green manures, natural fertilizers, residues from biological processes, fermented in solid-state (Farinas, 2015), bio-organic fertilizers (Chen et al., 2011; Zhao et al., 2011), poultry manure (Hirzel et al., 2010), lupine meal (Li et al., 2009; Li et al., 2015), and blood meal (Ciavatta et al., 1997). These can supply nutrients either through mineralization processes or by releasing them directly into the soil (Tamada, 2004; Hanson, 2006; Bañados et al., 2012; Hirzel et al., 2012; Retamales and Hancock, 2012), resulting in a key point to consider when choosing an organic fertilizer based on the physicochemical properties of the soil.

As these nitrogen sources used as organic fertilizers have different physicochemical characteristics, they can affect soil ecosystems, as well as the chemical, physical, and biological properties of the soil. Therefore it is important to know the impact of organic fertilizers on soil properties in order to determine their potential benefits or adverse effects in organic farming (Pinochet et al., 2000; Cayuela et al., 2009). For example, soil $\mathrm{pH}$ can be affected by $\mathrm{Al}$ and $\mathrm{H}$ concentrations, and also the availability of exchangeable bases, such as $\mathrm{Ca}, \mathrm{Mg}, \mathrm{K}$, and $\mathrm{Na}$ (Castro and Crusciol, 2013; Fageria and Nascente; 2014; Fageria et al., 2014; Moreira et al., 2015). Other soil chemical properties that can be affected by the addition of different nutritional sources are essential nutrients, such as $\mathrm{N}, \mathrm{P}, \mathrm{S}$ and some micronutrients (Hirzel et al., 2007; 2010; Castro and Crusciol, 2013).

The objective of this study was to evaluate the effect of seven organic fertilizers and a conventional source on soil $\mathrm{pH}$, salinity, and the chemical properties of two soils with contrasting characteristics (from the central-south and south of Chile), using fertilization under controlled conditions.

\section{MATERIALS AND METHODS}

\section{Soils}

Soil samples were collected from two different locations of the central-south and south of Chile, corresponding to "Virquenco", Santa Fe soil series $\left(37^{\circ} 27^{\prime} 35,81^{\prime \prime}\right.$ S; $\left.72^{\circ} 30^{\prime} 02,04^{\prime \prime} \mathrm{W}\right)$ of sandy loam texture (Aquic Haploxeroll); and "Villarrica", Villarrica soil series $\left(39^{\circ} 11^{\prime} 53^{\prime \prime}\right.$ S, $72^{\circ} 15^{\prime} 38^{\prime \prime} \mathrm{W}$ ) of silty loam texture (Acrudoxic Fulvudand) (CIREN, 1999; 2002; USDA, 2014). Soil samples were collected from 0 to $0.2 \mathrm{~m}$ of soil depth, and transported in bags with insulation to the Soil Laboratory of the Chilean Agriculture Research Institute. Soil samples were dried and sieved to 2 $\mathrm{mm}$. The physicochemical properties of the soils are shown in Table 1.

\section{Fertilization treatments}

The fertilization treatments were: 1) No fertilizer application (CT) as indicator of soil nutrient supply; 2) Compost of plant origin (CO) $\left(\mathrm{N}: \mathrm{P}_{2} \mathrm{O}_{5}: \mathrm{K}_{2} \mathrm{O} ; 0.84: 0.80: 0.45\right.$ and $\mathrm{C} / \mathrm{N}$ ration 11.96$)$, powder formulation; 3) Fertil (F) protein Nitrogen from enzymatic hydrolysis $\left(\mathrm{N}: \mathrm{P}_{2} \mathrm{O}_{5}: \mathrm{K}_{2} \mathrm{O} ; 12: 0: 0\right.$ and $\mathrm{C} / \mathrm{N}$ ratio 7.60 ), pellet; 4 ) Purely Grow (PG) plant-based proteins and hydrolyzed fish protein concentrate $\left(\mathrm{N}_{2} \mathrm{P}_{2} \mathrm{O}_{5}: \mathrm{K}_{2} \mathrm{O} ; 13.1: 0.0: 4.0\right.$ and $\mathrm{C} / \mathrm{N}$ ratio 6.20), liquid; 5) Purely Lysine (PL) plantbased proteins and hydrolyzed fish protein concentrate $\left(\mathrm{N}: \mathrm{P}_{2} \mathrm{O}_{5}: \mathrm{K}_{2} \mathrm{O} ; 15.5: 0.0: 0.0\right.$ and $\mathrm{C} / \mathrm{N}$ ratio 5.80), pellet; 6) Blood meal (BM) $\left(\mathrm{N}_{2} \mathrm{P}_{2} \mathrm{O}_{5}: \mathrm{K}_{2} \mathrm{O}\right.$; 14.5:0.27:0.6 and $\mathrm{C} / \mathrm{N}$ ratio 3.74), powder; 7) Lupine meal (LM) ( $\mathrm{N}: \mathrm{P}_{2} \mathrm{O}_{5}: \mathrm{K}_{2} \mathrm{O} ; 7.93: 0.90: 1.00$ and $\mathrm{C} / \mathrm{N}$ ratio 5.67$)$, ground grain; 8) Sodium nitrate (SN) ( $\left.\mathrm{N}_{2} \mathrm{P}_{2} \mathrm{O}_{5}: \mathrm{K}_{2} \mathrm{O} ; 15.0: 0.0: 9.0\right)$, granules; and 9) conventional fertilization (CF) with urea, triple superphosphate and potassium sulphate $\left(\mathrm{N}: \mathrm{P}_{2} \mathrm{O}_{5}: \mathrm{K}_{2} \mathrm{O} ; 45.0: 15.8: 29.7\right)$, granules. Treatments $2,3,4,5,6,7$ and 8 are fertilizers allowed for use in organic production; treatments 3, 4, 6 and 8 meet the requirements of the National Organic Program (NOP) (USDA, 2017). The total N rate applied to all the treatments, except $\mathrm{CT}$, was equivalent to $100 \mathrm{mg} \mathrm{kg}^{-1}$.

\section{Soil incubation}

Samples of each soil (100 g) were placed into $0.25 \mathrm{~L}$ plastic jars, moistened to $80 \%$ of their water holding capacity (equivalent to 0.33 bar) and incubated under controlled conditions at 25 $\pm 2^{\circ} \mathrm{C}$ in a refrigerated incubator (Velp Scientifica, model FOC 225E, UsmateVelate, Italy) for 16 wk. The jars were left opened for $1 \mathrm{~h}$, while soil moisture was adjusted gravimetrically two times on a weekly basis (Hirzel et al., 2010). Four replicates of each fertilization treatment were randomly collected at each sampling date $(0,1,2$, 
Table 1. Physicochemical properties of Virquenco and Villarrica soils $(0-20 \mathrm{~cm})$ prior to the experiment.

\begin{tabular}{|c|c|c|}
\hline \multirow[t]{2}{*}{ Parameter } & \multicolumn{2}{|c|}{ Soil } \\
\hline & Virquenco & Villarrica \\
\hline Clay, $\%$ & 8.3 & 23.0 \\
\hline Silt, \% & 43.2 & 57.6 \\
\hline Sand, \% & 48.5 & 19.4 \\
\hline Water retention at $0.33 \mathrm{bar}, \%$ & 19.15 & 83.89 \\
\hline Water retention at $15.00 \mathrm{bar}, \%$ & 12.09 & 56.45 \\
\hline Bulk density, $\mathrm{g} \mathrm{cc}^{-1}$ & 1.31 & 0.56 \\
\hline $\mathrm{pH}$, soil:water $1: 5$ & 6.55 & 5.72 \\
\hline Organic matter, $\mathrm{g} \mathrm{kg}^{-1}$ & 42.2 & 282.7 \\
\hline Electrical conductivity, $\mathrm{dS} \mathrm{m}^{-1}$ & 0.07 & 0.13 \\
\hline Available N, $\mathrm{mg} \mathrm{kg}^{-1}$ & 23.4 & 76.0 \\
\hline Available $\mathrm{P}, \mathrm{mg} \mathrm{kg}^{-1}$ & 14.0 & 11.8 \\
\hline Exchangeable $\mathrm{K}, \mathrm{cmol}_{+} \mathrm{kg}^{-1}$ & 0.42 & 0.36 \\
\hline Exchangeable $\mathrm{Ca}, \mathrm{cmol}_{+} \mathrm{kg}^{-1}$ & 5.97 & 10.08 \\
\hline Exchangeable $\mathrm{Mg}, \mathrm{cmol}_{+} \mathrm{kg}^{-1}$ & 1.58 & 0.85 \\
\hline Exchangeable $\mathrm{Na}, \mathrm{cmol}_{+}^{+} \mathrm{kg}^{-1}$ & 0.34 & 0.08 \\
\hline Exchangeable $\mathrm{Al}, \mathrm{cmol}_{+} \mathrm{kg}^{-1}$ & 0.03 & 0.09 \\
\hline Available Fe, $\mathrm{mg} \mathrm{kg}^{-1}$ & 50.27 & 69.15 \\
\hline Available Mn, mg kg-1 & 2.82 & 3.89 \\
\hline Available $\mathrm{Zn}, \mathrm{mg} \mathrm{kg}^{-1}$ & 0.71 & 3.78 \\
\hline Available $\mathrm{Cu}, \mathrm{mg} \mathrm{kg}^{-1}$ & 1.48 & 1.08 \\
\hline Available B, $\mathrm{mg} \mathrm{kg}^{-1}$ & 0.30 & 0.38 \\
\hline Available $\mathrm{S}, \mathrm{mg} \mathrm{kg}^{-1}$ & 3.0 & 16.1 \\
\hline
\end{tabular}

4, 8 and $16 \mathrm{wk}$ ) for analysis of $\mathrm{pH}$, EC (electrical conductivity), $\mathrm{P}, \mathrm{K}, \mathrm{Ca}, \mathrm{Mg}$ and $\mathrm{S}$.

\section{Soil measurements}

Chemical properties were analyzed using the method described by Sadzawka et al. (2006). Soil $\mathrm{pH}$ was measured in a 1:2.5 soil/water solution ratio with a $\mathrm{pH}$ electrode. Soil organic matter $(\mathrm{OM})$ was determined by the Walkley-Black wet digestion method. Electrical conductivity was evaluated using a conductivity cell (soil:water ratio 1:5). The general characterization considered the measurement of soil available $\mathrm{N}\left(\mathrm{NO}_{3}-\mathrm{N}\right.$ and $\left.\mathrm{NH}_{4}-\mathrm{N}\right)$ that was extracted with $2 \mathrm{~mol} \mathrm{~L}^{-1} \mathrm{KCl}$ and determined by colorimetry in a Skalar autoanalyzer (segmented flux spectrophotometer). Available $\mathrm{P}$ was determined by $0.5 \mathrm{~mol} \mathrm{~L}^{-1} \mathrm{NaHCO}_{3}$ (Olsen-P) using ascorbic acid-molybdate. Exchangeable $\mathrm{Ca}, \mathrm{Mg}, \mathrm{K}$, and $\mathrm{Na}$ were determined using $1 \mathrm{~mol} \mathrm{~L}^{-1} \mathrm{NH}_{4} \mathrm{OAc}$ extraction followed by flame spectroscopy, that is, absorption ( $\mathrm{Ca}$ and $\mathrm{Mg}$ ) and emission ( $\mathrm{K}$ and $\mathrm{Na}$ ). The soil exchangeable $\mathrm{Al}$ concentration was determined by $1 \mathrm{~mol} \mathrm{~L}^{-1} \mathrm{KCl}$ extraction with absorption spectroscopy. Soil $\mathrm{Fe}, \mathrm{Mn}, \mathrm{Zn}$, and $\mathrm{Cu}$ concentrations were determined in di-ethylene- triamine-penta-acetic acid (DTPA) extract by atomic absorption spectrometry (AAS) (Lindsay and Norvell, 1978). Boron (B) was determined by colorimetry in a solution obtained with hot water. Available S in the soil was extracted with calcium phosphate and determined by turbidimetry. Finally, soil texture was analyzed by the Bouyoucus hydrometer method (Bouyoucos, 1962) and bulk density was determinate by the cylinder method.

\section{Statistical analysis}

Each soil was analyzed separately due to their contrasting characteristics (Table 1). The experiment was conducted using a split-plot design. The main plot was the incubation time, while the sub-plot was the fertilization treatment. ANOVA, mean separation test (Tukey), and separation of interactions by contrasts were performed at the 5\% significance level, using SAS 8.0 (SAS Institute, Cary, North Carolina, USA). Contrast analyses were used to separate the interactions between incubation time and fertilization treatment. 


\section{RESULTS AND DISCUSSION}

\section{Soil physicochemical properties}

As can be observed in Table 1, clay content was lower in Virquenco soil. Villarrica soil had the highest silt content and the lowest sand content. Both soil series had a slightly acid $\mathrm{pH}$ and low salinity (as electrical conductivity, EC). Sulfur and $\mathrm{Zn}$ were deficient in Virquenco soil, while Boron was deficient in both soils. The other chemical properties of these soils are not restrictive for most of the crops (Hossain et al., 2015).

\section{Virquenco soil}

Incubation time $(\mathrm{T})$ had an effect on all the parameters evaluated $(\mathrm{p}<0.01)(\mathrm{pH}, \mathrm{EC}, \mathrm{P}$, $\mathrm{K}, \mathrm{Ca}, \mathrm{Mg}$, and S) (Table 2), while fertilization treatment $(\mathrm{F})$ affected $(\mathrm{p}<0.01) \mathrm{pH}, \mathrm{EC}, \mathrm{P}, \mathrm{K}, \mathrm{Ca}$, and S (Table 2). These parameters also showed $\mathrm{T} * \mathrm{~F}$ interaction $(\mathrm{p}<0.01$ and $\mathrm{p}<0.05)$ (Table 2). Changes over time for $\mathrm{pH}, \mathrm{EC}$, available $\mathrm{P}$, exchangeable $\mathrm{K}$, exchangeable $\mathrm{Ca}$, exchangeable $\mathrm{Mg}$ and available $\mathrm{S}$ are presented in Figs.1a, 2a, 3a, $4 a, 5 a, 6 a$ and $7 a$, respectively. The effect of each fertilization treatment, as observed in the average value recorded for each parameter during the incubation time, is presented in Table 3.

The highest $\mathrm{pH}$ value was obtained in $\mathrm{CO}$ $(p<0.05)$ (Table 3$)$, which might be an effect of the complexation of exchangeable $\mathrm{Al}$ in the $\mathrm{OM}$ of the compost (Damatto Júnior et al., 2006). A decrease in soil $\mathrm{pH}$ was observed in all the treatments with respect to $\mathrm{CO}$ (Table 3 ), while $\mathrm{CT}$ was higher than the other treatments, except $\mathrm{BM}$. There were no differences between $\mathrm{F}, \mathrm{PG}$, $\mathrm{LM}, \mathrm{CF}$ and BM $(\mathrm{p}>0.05)$, which were all higher

Table 2. Significance levels for the parameters evaluated in the experiment.

\begin{tabular}{|c|c|c|c|c|c|c|}
\hline \multirow[b]{2}{*}{ Parameter } & \multicolumn{3}{|c|}{ Virquenco soil } & \multicolumn{3}{|c|}{ Villarrica soil } \\
\hline & $\begin{array}{l}\text { Incubation time } \\
\text { (T) }\end{array}$ & $\begin{array}{l}\text { Treatment } \\
\text { (F) }\end{array}$ & $\begin{array}{c}\text { Interaction } \\
\qquad \mathrm{T} * \mathrm{~F}\end{array}$ & $\begin{array}{l}\text { Incubation time } \\
\text { (T) }\end{array}$ & $\begin{array}{l}\text { Treatment } \\
\text { (F) }\end{array}$ & $\begin{array}{c}\text { Interaction } \\
\quad T * F\end{array}$ \\
\hline $\mathrm{pH}$ & ** & $* *$ & $* *$ & $* *$ & $* *$ & $* *$ \\
\hline EC & $* *$ & $* *$ & $* *$ & $* *$ & $* *$ & $* *$ \\
\hline $\mathrm{P}$ & $* *$ & $* *$ & $* *$ & $* *$ & $* *$ & $* *$ \\
\hline $\mathrm{K}$ & ** & ** & * & ** & ** & ** \\
\hline $\mathrm{Ca}$ & $* *$ & $* *$ & $* *$ & $* *$ & ns & * \\
\hline $\mathrm{Mg}$ & $* *$ & ns & $* *$ & $* *$ & $* *$ & $* *$ \\
\hline$S$ & $* *$ & $* *$ & $* *$ & $* *$ & $* *$ & $* *$ \\
\hline
\end{tabular}

Significances: ${ }^{*} p<0.05 ;{ }^{* *} p<0.01 ;$ ns: non-significant results.

Table 3. Contrast analysis between fertilization treatments for each soil as the average value of all the evaluation period.

\begin{tabular}{|c|c|c|c|c|c|c|c|c|c|}
\hline aco soil & CT & $\mathrm{CO}$ & $F$ & PG & PL & BM & LM & SN & CF \\
\hline 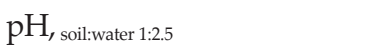 & $35 b$ & $6.47 a$ & $25 c$ & $6.24 \mathrm{~cd}$ & $6.08 \mathrm{e}$ & bc & $6.27 \mathrm{c}$ & $6.18 \mathrm{~d}$ & $6.24 \mathrm{~cd}$ \\
\hline & & & $6 \mathrm{e}$ & & & & & $26 a$ & $0.18 \mathrm{~d}$ \\
\hline & $14.1 \mathrm{c}$ & $20.2 a$ & $13.9 \mathrm{~cd}$ & $13.8 \mathrm{~cd}$ & & & & \multicolumn{2}{|c|}{$13.7 \mathrm{~cd} 15.8 \mathrm{~b}$} \\
\hline $\mathrm{g} \mathrm{kg}^{-1}$ & $168 \mathrm{~d}$ & $239 a$ & $167 d$ & $195 c$ & $165 d$ & $167 d$ & $176 \mathrm{~d}$ & \multicolumn{2}{|c|}{$215 b \quad 214 b$} \\
\hline $\mathrm{kg}^{-1}$ & $6.4 \mathrm{ab}$ & $6.8 \mathrm{a}$ & $6.5 \mathrm{ab}$ & $6.6 \mathrm{ab}$ & $6.1 \mathrm{~b}$ & 6.01 & 6. & $6.0 \mathrm{~b}$ & 6.3ab \\
\hline & & & & & & & & $1.72 \mathrm{a}$ & $1.83 a$ \\
\hline Avá & $1.70 \mathrm{~b}$ & 1. & $53 b$ & $1.75 b$ & $1.48 \mathrm{~b}$ & 1 . & 1. & $1.70 \mathrm{~b}$ & $24.3 \mathrm{a}$ \\
\hline & & & $\mathrm{F}$ & P & PL & & & & $\mathrm{CF}$ \\
\hline & & & $50 \mathrm{c}$ & $5.47 \mathrm{~cd}$ & & & & $.50 \mathrm{bc}$ & 5.5 \\
\hline & & 0.29 de & $0.33 b c$ & $0.40 \mathrm{a}$ & $0.39 a$ & & & $0.40 \mathrm{a}$ & $0.36 \mathrm{~b}$ \\
\hline & & & $11.7 \mathrm{~cd}$ & $11.5 \mathrm{~d}$ & $11.7 \mathrm{~cd}$ & & & $12.0 \mathrm{~b}$ & $12.4 \mathrm{a}$ \\
\hline & 129de & & le 1 & $153 b c$ & $126 \mathrm{e}$ & & & $177 a$ & $164 b$ \\
\hline 5 & $10.5 a$ & & $10.7 \mathrm{a}$ & $10.5 a$ & $10.8 \mathrm{a}$ & & & $10.7 \mathrm{a}$ & $11.0 \mathrm{a}$ \\
\hline & $0.87 \mathrm{cde}$ & & $0.88 \mathrm{cde}$ & e $0.85 \mathrm{de}$ & $0.87 \mathrm{cde}$ & e 0.88 & & $0.90 \mathrm{bc}$ & 0.93 \\
\hline Availa & $26.4 \mathrm{ab}$ & 25.2abc & 24.4abcd & d 21.7de & $19.9 \mathrm{e}$ & 23.6bcd & $22.9 \mathrm{~cd}$ & 24.3abcd & d 26.6a \\
\hline
\end{tabular}

Different letters in the same row indicate significant differences between treatments according to Tukey's test ( $p<0.05)$. Abbreviations: CT: Control without fertilization; CO: Compost; F: Fertil; PG: Purely Grow; PL: Purely Lysine; LM: Lupine Meal; BM: Blood Meal; SN: Sodium Nitrate; CF: Conventional Fertilization. 
than PL ( $\mathrm{p}<0.05)$. The lowest $\mathrm{pH}$ value obtained with the use of PL could be associated with a higher ammonia release; ammonia is nitrified afterwards, reducing soil $\mathrm{pH}$, as well as the stimulant effect of $\mathrm{N}$ over the mineralization of organic matter, and therefore, organic acid production (Fageria and Nascente, 2014). Values obtained (Fig. 1a) showed a decrease in soil pH during the incubation time except in BM, PL and $\mathrm{CO}$, which showed an increase at $7 \mathrm{~d}$ incubation. All these changes could be related to chemical reaction processes involved in mineralization and nutrient release (Kirchmann et al., 2007; Hirzel et al., 2010; Fageria and Nascente, 2014). These results differ from those reported by Bulluck et al. (2002), who found that soil pH increased with organic amendments due to $\mathrm{Al}$ complexation and an increase in basic cations in the soil solution. Al content in Virquenco soil was very low (Table 1 ).

The highest EC value (Table 3) was recorded in $\mathrm{SN}(\mathrm{p}<0.05)$, which can be explained by its $\mathrm{Na}$ content. The second highest $\mathrm{EC}$ value was obtained in PL $(p<0.05)$, which could be associated with its ammonia concentration. Differences were also observed between the other treatments, while the lowest value was obtained in CT and CO. The lack of fertilization in CT and the slow rate of nutrient release described for $\mathrm{CO}$ can account for this situation (Cooperband et al., 2002). In general, the EC was low in all the treatments, which is considered as having no effects in agriculture. However, these results are not consistent with those reported by Jiménez-Becker et al. (2010), who described an increase in EC when compost of manure was used, compared to compost of plant origin and a control without compost. Regarding EC (Fig. 2a), all treatments had an increase during the incubation time, associated with organic matter mineralization and release of nutrients (Kirchmann et al., 2007; Hirzel et al., 2010; Fageria and Nascente, 2014). All treatments showed interaction between incubation time and fertilization treatment (Table 2); this could be related to different rates of $\mathrm{N}$ release and other nutrients (Li et al., 2015; Muñoz-Vega et al., 2016).

The highest available $\mathrm{P}$ concentration was observed in $\mathrm{CO}(\mathrm{p}<0.05)$ (Table 3$)$, with
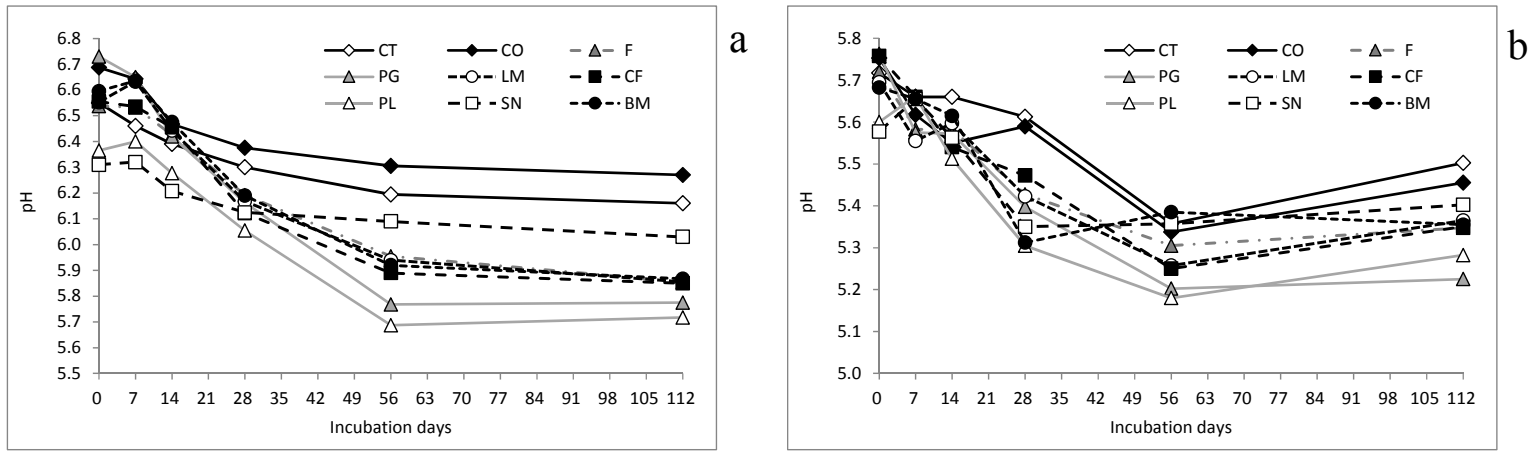

Fig. 1. Evolution of soil $\mathrm{pH}$ during the incubation time. a) Virquenco soil; b) Villarrica soil.

Abbreviations: CT: Control without fertilization; CO: Compost; F: Fertil; PG: Purely Grow; PL: Purely Lysine; LM: Lupine Meal; BM: Blood Meal; SN: Sodium Nitrate; CF: Conventional Fertilization.
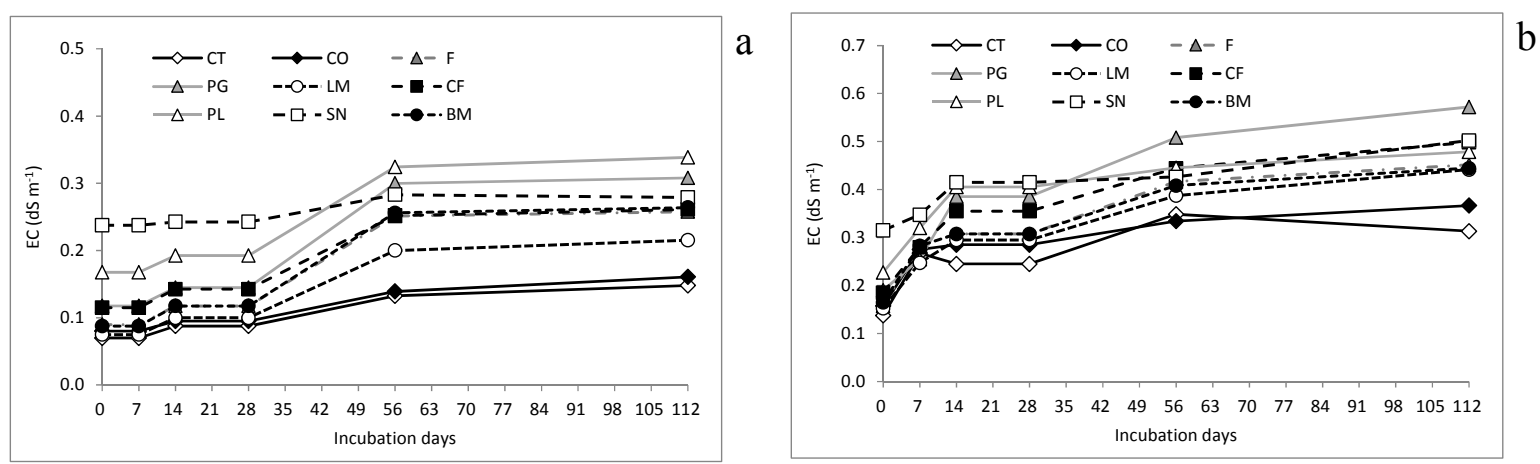

Fig. 2. Evolution of soil electrical conductivity (EC) during the incubation time. a) Virquenco soil; b) Villarrica soil.

Abbreviations: CT: Control without fertilization; CO: Compost; F: Fertil; PG: Purely Grow; PL: Purely Lysine; LM: Lupine Meal; BM: Blood Meal; SN: Sodium Nitrate; CF: Conventional Fertilization. 
differences between the other treatments. On the other hand, the lowest value was obtained in PL, BM, SN, LM, PG, F and PL $(p<0.05)$. All treatments had an average $\mathrm{P}$ concentration similar to that recorded at the beginning of the experiment (Table 1), except $\mathrm{CO}$ since this treatment showed an increase of $6 \mathrm{mg} \mathrm{kg}^{-1}$ with respect to the initial concentration. This increase in $\mathrm{P}$ concentration could be related to reactions of anionic exchange with organic compounds derived from compost mineralization (Eghball, 2002; Eghball et al., 2004). The evolution of $P$ concentration (Fig. 3a) showed an increase until the 28-d in all treatments, followed by a decrease. In general, all treatments had small changes during the incubation time, with differences between times shown by the interactions between incubation time and fertilization treatment (Table 2). For treatments with high organic fraction, such as CO, LM and BM, these results do not agree with those of Herencia et al. (2007) and Silva et al. (2016), who proposed that the use of organic amendments increases P solubility, which could respond to an effect of organization of $\mathrm{P}$ associated with biological activity and formation of complex of organic compounds.

The highest $\mathrm{K}$ concentration was observed in $\mathrm{CO}(\mathrm{p}<0.05)$ (Table 3$)$, followed by SN and CF $(\mathrm{p}<$ $0.05)$, with no differences between $C F$ and PG ( $p>$ $0.05)$. The lowest $K$ concentrations were obtained in treatments $\mathrm{CT}, \mathrm{F}, \mathrm{LM}, \mathrm{PL}$ and $\mathrm{BM}$, with no differences between them $(p>0.05)$. The higher $\mathrm{K}$ concentration in treatments $\mathrm{CO}, \mathrm{SN}$ and $\mathrm{CF}$ could be explained by their $\mathrm{K} / \mathrm{N}$ ratio $0.54,0.60$, and 0.66 , respectively. Increases in $\mathrm{K}$ concentration using compost have been previously described by other authors (Jiménez-Becker et al., 2010; Bustamante et al., 2011). Regarding the initial K concentration of the soils (Table 1 ), it was observed that the CO, PG, SN and CF resulted in an increase in $\mathrm{K}$ concentration (Table 3), with some changes during the incubation time (Fig. 4a) as confirmed by the interaction between incubation time and fertilization treatment (Table 2). This increase in $\mathrm{K}$ concentration could respond to reactions of desorption from the clay fraction.
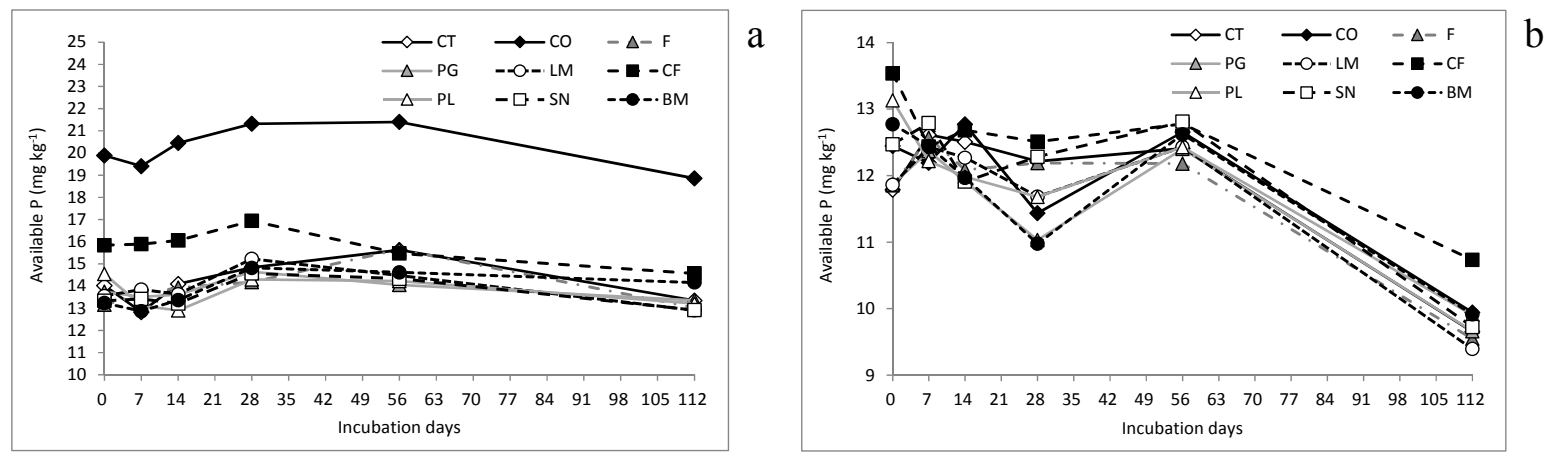

Fig. 3. Evolution of soil available phosphorous (P) during the incubation time. a) Virquenco soil; b) Villarrica soil.

Abbreviations: CT: Control without fertilization; CO: Compost; F: Fertil; PG: Purely Grow; PL: Purely Lysine; LM: Lupine Meal; BM: Blood Meal; SN: Sodium Nitrate; CF: Conventional Fertilization.
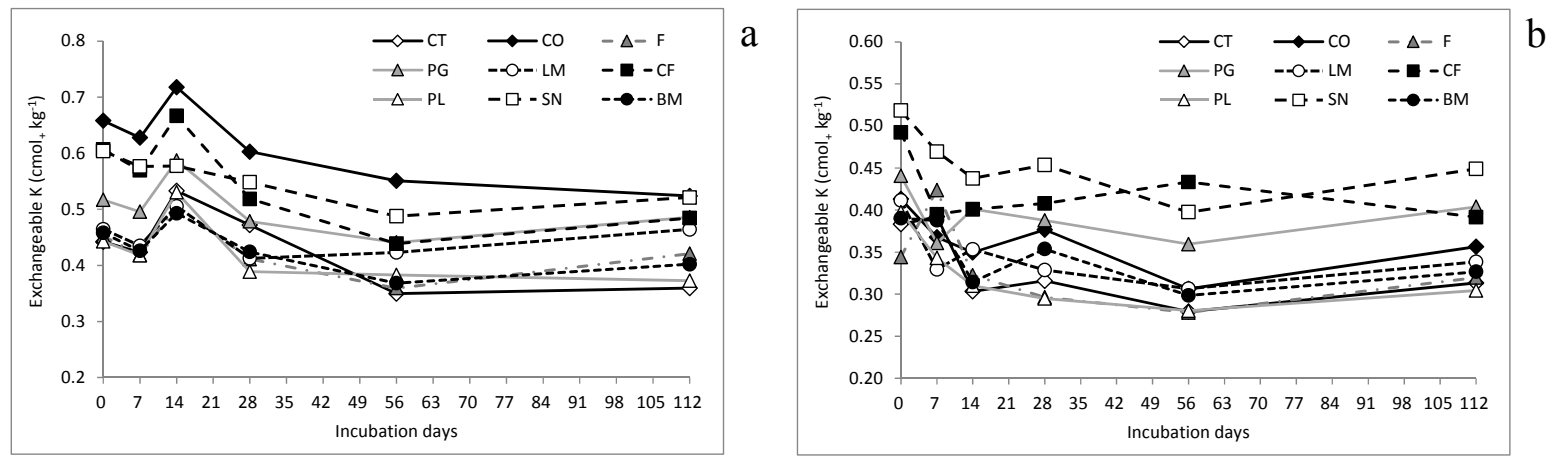

Fig. 4. Evolution of soil exchangeable potassium (K) during the incubation time. a) Virquenco soil; b) Villarrica soil.

Abbreviations: CT: Control without fertilization; CO: Compost; F: Fertil; PG: Purely Grow; PL: Purely Lysine; LM: Lupine Meal; BM: Blood Meal; SN: Sodium Nitrate; CF: Conventional Fertilization. 
Ca concentration showed small differences between treatments (Table 3 and Fig. 5a). Few changes were observed during the incubation time (Fig. 5a) as shown in the interaction analysis (Table 2). The highest average Ca concentration was obtained with $\mathrm{CO}$, which was different from values of $\mathrm{PL}, \mathrm{BM}, \mathrm{LM}$ and $\mathrm{SN}(\mathrm{p}<0.05)$, with no differences between these treatments $(p>0.05)$. Ca concentrations during the incubation time (Fig. 5a) increased at 7-day with the use of LM, PG, CF and PL, but it showed a sharp decrease in LM between 56 and $112 \mathrm{~d}$. These changes over the time have been reported by Hirzel et al. (2016) for short incubation times with different calcium fertilizers in two soils of loam and clay loam texture.

No differences were found between treatments ( $p>0.05$ ) for $\mathrm{Mg}$ (Table 3). In general, values were slightly higher than the initial concentrations (Table 1). Regarding the evolution of $\mathrm{Mg}$ concentration, some changes were observed (Fig. 6a) as demonstrated by the interaction between incubation time and fertilization treatment (Table 2). The biggest changes were observed during the first $28 \mathrm{~d}$ incubation (Fig. 6a). Variations in the concentrations of either exchangeable or available $\mathrm{Mg}$ during short incubation periods with different soils and fertilization treatments have been previously reported by Hirzel et al. (2016), and they have been associated with variations in the soil $\mathrm{pH}$ as an effect of a higher desorption of cations under a reduction of soil $\mathrm{pH}$ during the incubation period (Havlin et al., 1999; Fageria and Nascente, 2014).

CF had the highest concentration of $S(p<0.05)$, with no differences between the other treatments $(p>0.05)$ (Table 3). The higher $S$ concentration in $\mathrm{CF}$ was previously discussed and explained by the $S$ concentration in the potassium sulfate used as fertilizer. In addition, the absence of differences between the other treatments might be explained by the low or no $S$ content of each fertilization treatment. The average $S$ value in all treatments, except $\mathrm{CF}$ and $\mathrm{F}$, was slightly lower than the initial concentration (Table 1). Regarding the evolution of $S$ concentration, all treatments, except $\mathrm{CF}$, showed small changes
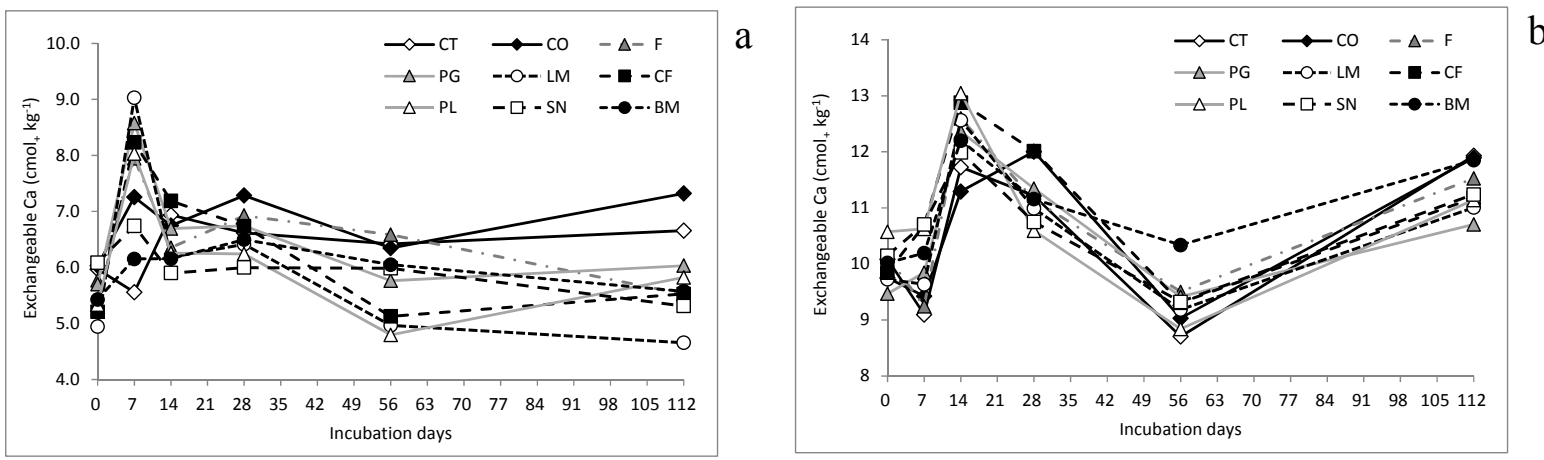

Fig. 5. Evolution of soil exchangeable calcium (Ca) during the incubation time. a) Virquenco soil; b) Villarrica soil.

Abbreviations: CT: Control without fertilization; CO: Compost; F: Fertil; PG: Purely Grow; PL: Purely Lysine; LM: Lupine Meal; BM: Blood Meal; SN: Sodium Nitrate; CF: Conventional Fertilization.

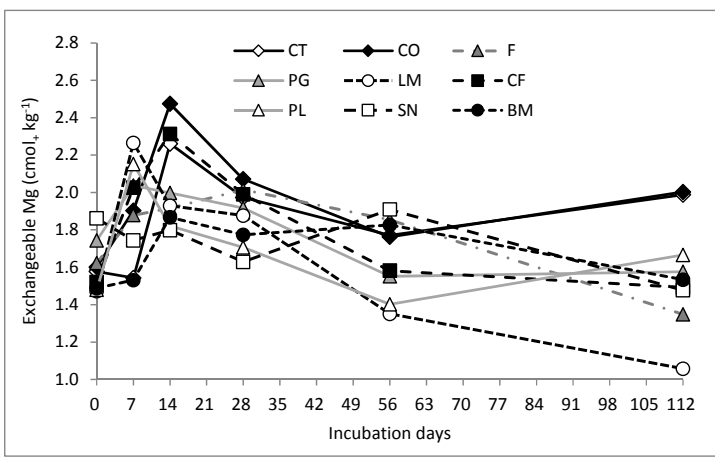

a

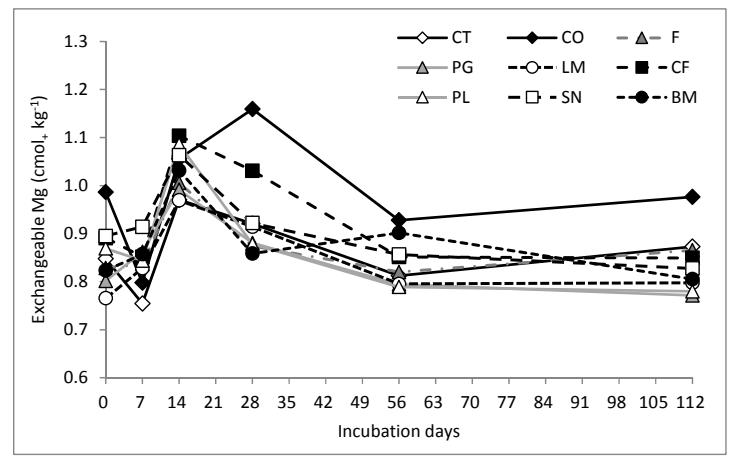

Fig. 6. Evolution of the soil exchangeable magnesium $(\mathrm{Mg})$ during the incubation time. a) Virquenco soil; b) Villarrica soil.

Abbreviations: CT: Control without fertilization; CO: Compost; F: Fertil; PG: Purely Grow; PL: Purely Lysine; LM: Lupine Meal; BM: Blood Meal; SN: Sodium Nitrate; CF: Conventional Fertilization. 
during the incubation time, while $\mathrm{CF}$ had a strong decrease from 0 to $7 \mathrm{~d}$, followed by an increase until the 28-d (Fig. 7a). Most of the treatments recorded a decrease until the 56-d (Fig. 7a), and this situation along with the changes observed during all the incubation time are demonstrated by the interaction between incubation time and fertilization treatment (Table 2).

\section{Villarrica soil}

Incubation time $(\mathrm{T})$ had an effect $(\mathrm{p}<0.01)$ on all parameters evaluated $(\mathrm{pH}, \mathrm{EC}, \mathrm{P}, \mathrm{K}, \mathrm{Ca}$, $\mathrm{Mg}$, and S) (Table 2). Fertilization treatment $(\mathrm{F})$ affected $(\mathrm{p}<0.01)$ most of the parameters in Villarrica soil (pH, EC, $\mathrm{P}, \mathrm{K}, \mathrm{Mg}$, and S) (Table 2). These parameters were also affected by the $\mathrm{T} * \mathrm{~F}$ interaction $(p<0.01$ and $p<0.05)$ (Table 2). The evolution over the time for $\mathrm{pH}, \mathrm{EC}$, available $\mathrm{P}$, exchangeable $\mathrm{K}$, exchangeable $\mathrm{Ca}$, exchangeable $\mathrm{Mg}$ and available $\mathrm{S}$ are presented in Figs. $1 \mathrm{~b}, 2 \mathrm{~b}$, $3 b, 4 b, 5 b, 6 b$, and $7 b$, respectively. The effect of each fertilization treatment, as observed in the average value recorded for each parameter during the incubation time, is presented the Table 3.

The highest $\mathrm{pH}$ value was obtained in the CT treatment $(p<0.05)$, which was similar to $\mathrm{CO}$ $(\mathrm{p}>0.05)$ (Table 3$)$. The lowest $\mathrm{pH}$ values were obtained in PL and PG $(p<0.05)$ (Table 3). No differences were observed between $\mathrm{CO}, \mathrm{BM}, \mathrm{SN}$ and CF ( $p>0.05)$. Similarly, no differences were found between F, PG, BM, LM, SN and CF ( $p>$ $0.05)$. In general, all the treatments generated a $\mathrm{pH}$ from slightly acid to moderately acid (Table 3). The higher $\mathrm{pH}$ value obtained in CT may be explained by the no addition of fertilizer (nitrogen mainly), or due to nitrogen fertilization inducing a mineralization process that resulted in acidification of the soil in the other treatments (Kirchmann et al., 2007; Hirzel et al., 2010; Fageria and Nascente, 2014). The effect of CO on soil $\mathrm{pH}$ was previously discussed and associated with the complexation of exchangeable $\mathrm{Al}$ in the organic matter of the compost (Damatto Júnior et al., 2006). The lowest value of $\mathrm{pH}$ obtained with the use of PL and PG could be related to a higher N release (Mondini et al., 2008; MuñozVega et al., 2016), which also generates a higher concentration of ammonia that is nitrified afterwards, reducing soil $\mathrm{pH}$. Regarding $\mathrm{pH}$ evolution (Fig. 1b), all treatments showed a decrease in soil $\mathrm{pH}$ over time. The interaction between incubation time and fertilization treatment (Table 2) is observed in the different magnitudes of the decrease in $\mathrm{pH}$ during the incubation time between treatments (Fig. 1b). As for Virquenco soil, these results differ from those reported by Bulluck et al. (2002) for the use of organic amendments and their effect on increasing soil $\mathrm{pH}$.

The highest EC values were registered in PG, PL and SN treatments $(p<0.05)$ (Table 3$)$. The lowest EC value was obtained in CT $(p<0.05)$, associated with the absence of fertilization, which was similar to the value obtained with $\mathrm{CO}$, associated with its slow rate of $\mathrm{N}$ release (Eghball, 2002; Muñoz-Vega et al., 2016) and its buffer capacity on the ions present in the soil (Yang et al., 2012). The effect of SN on EC can be associated with its Na content, while that of PG and PL could be explained by their ammonia content and their high rate of $\mathrm{N}$ release (Muñoz-Vega et al., 2016). Regarding EC evolution (Fig. 2b), all treatments showed an increase during the incubation time, associated with $\mathrm{OM}$ mineralization and release of nutrients (Kirchmann et al., 2007; Hirzel et al., 2010; Fageria and Nascente, 2014). There were differences in the magnitude of these increases in each treatment during the incubation time. These were detected in the interaction analysis (Table 2) and could be associated with the different rates of $\mathrm{N}$ release and other nutrients (Li et al., 2015; Muñoz-Vega et al., 2016).
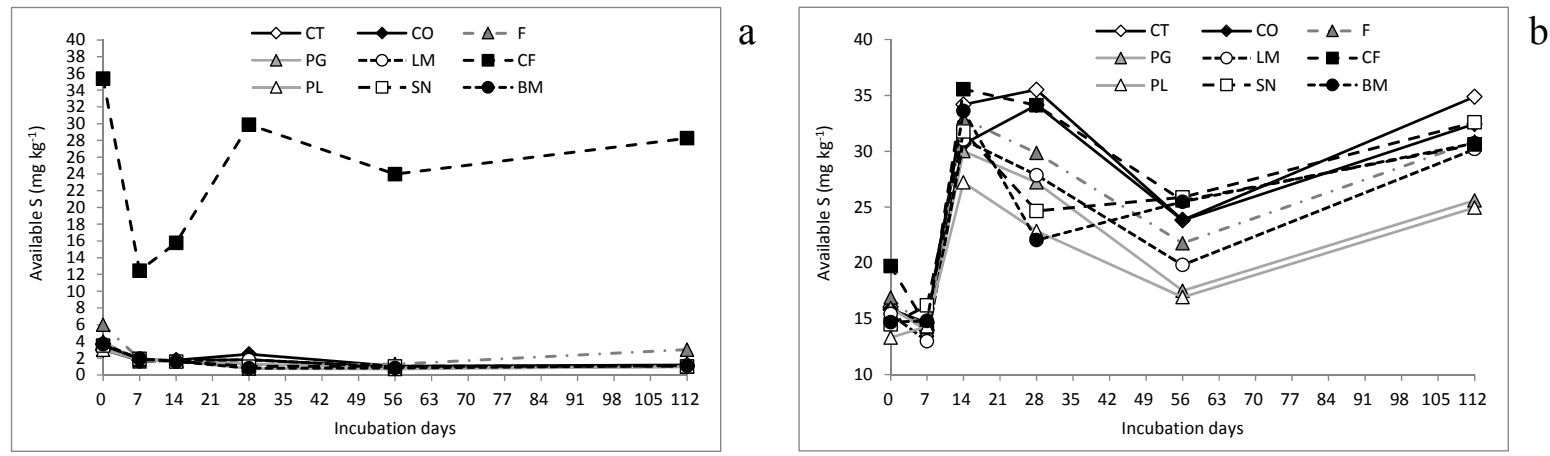

Fig. 7. Evolution of soil available sulfur (S) during the incubation time. a) Virquenco soil; b) Villarrica soil.

Abbreviations: CT: Control without fertilization; CO: Compost; F:Fertil; PG: Purely Grow; PL: Purely Lysine; LM: Lupine Meal; BM: Blood Meal; SN: Sodium Nitrate; CF: Conventional Fertilization. 
The highest available $\mathrm{P}$ concentration was observed in CF $(p<0.05)$ (Table 3), with differences between the other treatments. The lowest value was obtained in PG $(p<0.05)$, which was similar to F, PL, BM and LM ( $p>0.05)$. The results obtained showed that all the treatments presented a low $\mathrm{P}$ content (Table 3). For CO, BM, and CF treatments, organic acid concentration probably increased during the incubation time due to mineralization processes, which reduced the adsorption of $\mathrm{P}$ in the soil, increasing its availability (Laboski and Lamb, 2003; Herencia et al., 2007; Fageria and Nascente, 2014).The average $P$ concentration in all treatments was similar to the initial values (Table 1 ), except for $\mathrm{CF}$; this could be associated with the high $\mathrm{P}$ rate used as fertilization $(\mathrm{P} / \mathrm{N}$ ratio $=$ 0.35) and the speed of $P$ release of the fertilizer used (triple superphosphate). These results do not agree with those of Herencia et al. (2007) and Silva et al. (2016), who proposed that the use of organic amendments increases $\mathrm{P}$ solubility. In terms of the evolution of $\mathrm{P}$ concentration (Fig. $3 b)$, variable effects can be observed. An increase in available $\mathrm{P}$ was observed from day 0 to 7 in $\mathrm{LM}, \mathrm{CT}$ and $\mathrm{SN}$, but this decreased in CF and PG during the same period. No clear trend was observed between days 7 and 56 as some treatments showed either a decrease or an increase in P concentration. Finally, a strong decrease was observed from day 56 of incubation in all the treatments (Fig. 3b). These increases, decreases and differences in magnitude between treatments during the incubation time were detected with the interaction analysis (Table 2), and could be linked to the different rates of $\mathrm{N}$ release and other nutrients (Li et al., 2015; Muñoz-Vega et al., 2016), as well as the buffer effect of a soil with high OM content and high $\mathrm{Al}$ content as in Villarrica soil (Havlin et al., 1999; Barreal et al., 2001) (Table 1). Regarding Virquenco soil, Villarrica had lower P availability $(p<0.05)$, which was associated with its allophanic and imogolite clay content (Barreal et al., 2001; Matus et al., 2008; Hirzel et al., 2010).

For $\mathrm{K}$, the highest concentration was observed in $\mathrm{SN}(\mathrm{p}<0.05)$ (Table 3), followed by $\mathrm{CF}$ and $P G$, with no differences between them $(p>0.05)$. The lowest $\mathrm{K}$ concentrations were obtained in PL, BM, LM and F, without differences between these treatments and with CT. The highest $\mathrm{K}$ concentration obtained in $\mathrm{SN}$ is associated with its $\mathrm{K} / \mathrm{N}$ ratio (0.6). Moreover, a higher K concentration in the $\mathrm{CF}$ treatment can be associated with its high $\mathrm{K} / \mathrm{N}$ ratio (0.66). $\mathrm{K}$ concentration also showed a trend to decrease between the initial and final incubation time points. The changes in the evolution of $\mathrm{K}$ concentration of each treatment during the incubation time was detected in the interaction analysis (Table 2) and could be associated with the different rates of $\mathrm{N}$ release and other nutrients (Li et al., 2015; Muñoz-Vega et al., 2016), as well as the cation exchange in the secondary minerals of the ash volcanic soils, such as Villarrica soil (Havlin et al., 1999; Hirzel et al., 2010).

Ca concentration had no differences between treatments $(p>0.05)$ (Table 3$)$, which could be associated with the buffer capacity (Yang et al., 2012) and reactions of the cation exchange in the secondary minerals of this soil (Havlin et al., 1999; Hirzel et al., 2010). Compared to the initial Ca concentration of the soil (Table 1), values either remained similar or slightly increased during the incubation time (Table 3), and also recorded a lot of changes in the evolution of each treatment during the incubation time (Fig. 5b). These changes were detected in the interaction analysis (Table 2); they are related to reactions of cation exchange in the secondary minerals of the ash volcanic soils (Havlin et al., 1999; Hirzel et al., 2010), and also to changes in soil $\mathrm{pH}$ as an effect of a higher desorption of cations under a reduction of soil $\mathrm{pH}$ during the incubation period (Table 3, Figs. 1b, 4b, 5b, and 6b) (Fageria and Nascente, 2014; Havlin et al., 1999). Changes in the evolution of $\mathrm{Ca}$ concentration were also described by Hirzel et al. (2016) in soil incubated for a short period of time.

For $\mathrm{Mg}$ concentration, the highest value was obtained in $\mathrm{CO}(\mathrm{p}<0.05)$, which was similar to $\mathrm{CF}$ $(p>0.05)$ (Table 3). The lowest $\mathrm{Mg}$ concentration was obtained in $\mathrm{LM}(\mathrm{p}<0.05)$, which was similar to PL, PG, F and CT ( $p>0.05)$. This higher Mg concentration in $\mathrm{CO}$ can be explained by the composition of $\mathrm{CO}$ with a $0.38 \%$ of $\mathrm{Mg}$ (data not shown). The average value of $\mathrm{Mg}$ concentration was similar to the initial one (Tables 1 and 3), except for $\mathrm{CO}, \mathrm{CF}$ and $\mathrm{SN}$ treatments, which were higher than the initial value. Regarding the evolution of the $\mathrm{Mg}$ concentration of each treatment during the incubation time (Fig. 6b), several changes were observed as detected by the interaction analysis between both variation sources (Table 2). These changes in the cation concentration during the incubation time have been previously discussed for $\mathrm{K}$ and $\mathrm{Ca}$ (Havlin et al., 1999; Hirzel et al., 2010; Fageria and Nascente, 2014).

The highest $\mathrm{S}$ concentration was observed in $\mathrm{CF}$ $(\mathrm{p}<0.05)$ (Table 3$)$, which was similar to CT, CO, F and SN ( $p>0.05)$. The lowest $S$ concentration was obtained in PL $(\mathrm{p}<0.05)$, which was similar to PG $(\mathrm{p}>0.05)$. The higher $\mathrm{S}$ concentration in $\mathrm{CF}$ can be explained by the $18 \%$ of $S$ in the potassium sulfate used as fertilizer (data not shown). Regarding the initial S concentration (Table 1), there was an increase in the $\mathrm{S}$ concentration for all treatments 
(Table 3), considering the average value during the incubation time, which could be explained by the mineralization process of the soil organic matter (Havlin et al., 1999). The evolution of S concentration during the incubation time (Fig. $7 b)$ for each fertilization treatment showed many changes as observed in the interaction analysis (Table 2). In this sense, either a decrease or an increase in $\mathrm{S}$ concentration should have occurred from the 0 - $\mathrm{d}$ until the final incubation time period, but this did not occur (Fig. 7b). This trend in the evolution of $S$ concentration over the incubation period in Villarrica soil (Fig. 7b) was different from that observed for Virquenco soil (Fig. 7a). This can be explained by the biological activity in a soil with high OM content, like Villarrica (Table 1), which immobilizes this element ( $\mathrm{Wu}$ et al., 1993), and also by processes of adsorption of sulfates in the soil anionic exchange capacity (Barreal et al., 2001). The increase in available S after immobilization observed in Villarrica soil (Fig. 7b) between 7 and 14, and 56 and 112 days, may be a response of the biological activity, since $S$ mineralization is driven by the search for energy, which releases $S$ as a by-product (Blum et al., 2013).

\section{CONCLUSIONS}

The results in this study, which was conducted under controlled conditions, indicate that the use of organic fertilizers had different effects on soil $\mathrm{pH}$, salinity and concentrations of $\mathrm{P}, \mathrm{K}$, $\mathrm{Ca}, \mathrm{Mg}$, and $\mathrm{S}$ in two soils (sandy loam Mollisol and silty loam Andisol). None of the organic fertilizers registered the highest values for all parameters evaluated. However, the use of $\mathrm{CO}$ had the highest values of $\mathrm{pH}$, available $\mathrm{P}$, and exchangeable $\mathrm{K}, \mathrm{Ca}$, and $\mathrm{Mg}$. On the other hand, the PL treatment showed, in general, the lowest values for most of the parameters evaluated. For both soils, the evolution over time for each parameter had different trends that interacted with the fertilization treatment, and in general resulted in a steady decrease in $\mathrm{pH}$ and an increase in salinity. Finally, the two soils showed differences for the chemical parameters evaluated over time, which were mainly associated with the initial properties of each soil.

\section{ACKNOWLEDGEMENTS}

The authors would like to thank the financial support from the Foundation for Agricultural Innovation (FIA) through project PYT-2011-0064 and the Chilean company Hortifrut Chile S.A.

\section{LITERATURE CITED}

Bañados, M.P., B.C. Strick, D.R. Bryla, and T.L. Righetti. 2012. Response of highbush blueberry to nitrogen fertilizer during field establishment. I. Accumulation and allocation of fertilizer nitrogen and biomass. HortScience 47(5):648-655.

Barreal, M.E., M. Camps, F. Macías, and A.E. Fertita. 2001. Phosphate and sulfate retention by non volcanic soils with andic properties. Soil Science 166(10):691-707. doi:10.1097/00010694-200110000-00005.

Bouyoucos, G. 1962. Hydrometer method improved for making particle size analysis of soils. Agron. J. 54:464-465.

Blum, S.C., J. Lehmann, D. Solomon, E. FáveroCaires, and L.R. Ferracciú-Alleni. 2013. Sulfur forms in organic substrates affecting $S$ mineralization in soil. Geoderma 200-201:156164. doi:10.1016/j.geoderma.2013.02.003.

Bulluck, L.R., M. Brosius, G.K. Evanylo, and J.B. Ristaino. 2002. Organic and synthetic amendments influence in soil microbial, physical and chemical properties on organic and conventional farms. Appl. Soil Ecol. 19:147-160. doi:10.1016/S0929-1393(01)00187-1.

Bustamante, M.A., D. Said-Pullicino, E. Agulló, J. Audreu, and C. Paredes. 2011. Application of winery and distillery waste composts to a Jumilla (SE Spain) vineyard: effects on the characteristics of a calcareous sandyloam soil. Agric Ecosyst Environ. 140:80-87. doi:10.1016/j.agee.2010.11.014.

Castro, G.S.A., and C.A.C. Crusciol. 2013. Effects of superficial liming and silicate application on soil fertility and crop yield under rotation. Geoderma 195-196:234-242. doi:10.1016/j. geoderma.2012.12.006.

Cayuela, M.L., T. Sinicco, and C. Mondini. 2009. Mineralization dynamics and biochemical properties during initial decomposition of plant and animal residues in soil. Appl. Soil Ecol. 41:118-127. doi: 10.1016/j. apsoil.2008.10.001.

Chen, L., X. Yang, W. Raza, J. Luo, F. Zhang, and Q. Shen. 2011. Solid-state fermentation of agro-industrial wastes to produce bioorganic fertilizer for the biocontrol of Fusarium wilt of cucumber in continuously cropped soil. Bioresource Technology 102:3900-3910. doi:10.1016/j.biortech.2010.11.126.

Ciavatta, C., M. Govi, L. Sitti, and C. Gessa. 1997. Influence of blood meal organic fertilizer on soil organic matter: a laboratory study. J. Plant Nutr. 20(11):1573-1591. doi:10.1080/01904169709365358. 
CIREN. 1999. Descripciones de suelos materiales y símbolos: Estudio Agrológico VIII Región. Publicación CIREN № 121. 583 p. CIREN, Santiago, Chile.

CIREN. 2002. Descripciones de suelos materiales y símbolos: Estudio Agrológico IX Región. Publicación CIREN № 122. 360 p. CIREN, Santiago, Chile.

Cooperband, L., G. Bollero, and F. Coale. 2002. Effect of poultry litter and compost on soil nitrogen and phosphorus availability and corn production. Nutr. Cycl. Agroecosyst. 62:185-194. doi:10.1023/A:1015538823174.

Damatto Júnior, E.R., R.L. Villas Bôas, S. Leonel, e D.M. Fernandes. 2006. Alterações em propriedades de solo adubadocom doses de compost orgánico sob cultivo de bananeira. Rev. Bras. Frutic. 28:546-549. doi:10.1590/ S0100-29452006000300048.

Eghball, B. 2002. Soil properties as influenced by phosphorus and nitrogen based manure and compost applications. Agron. J. 94(1):128135.

Eghball, B., D. Ginting, and J.E. Gilley. 2004. Residual effects of manure and compost applications on corn production and soil properties. Agron. J. 96:442-447.

Epule, T.E., C.R. Bryant, C. Akkari, and O. Daouda. 2015. Can organic fertilizers set the pace for a green arable agricultural revolution in Africa? Analysis, synthesis and way forward. Land Use Pol. 47:179-187.

Fageria, N., and A. Nascente. 2014. Management of soil acidity of South American soils for sustainable crop production. Adv. Agron. 128:221-275.

Fageria, N.K., A. Moreira, L.A.C. Moraes, and M.F. Moraes. 2014. Influence of lime and gypsum on yield and yield components of soybean and changes in soil chemical properties. Com. Soil Sci. Plant Anal. 45:271283. doi:10.1016/B978-0-12-802139-2.00006-8.

Farinas, C. 2015. Developments in solid-state fermentation for the production of biomassdegrading enzymes for the bioenergy sector. Renew. Sust. Energy Rev. 52:179-188. doi:10.1016/j.rser.2015.07.092.

Hanson, E.J. 2006. Nitrogen fertilization of highbush blueberry. Acta Horticulturae 715:347-351. doi:10.17660/Acta Hortic.2006.715.51.

Havlin, J.L., S.L. Tisdale, W. Nelson, J. Havlin, and J. Beaton. 1999. Soil fertility and fertilizers. An introduction to nutrient management. $6^{\text {th }}$. ed. 503 p. Prentice-Hall, Upper Saddle River, New Jersey, USA.
Herencia, J.F., C. Ruiz-Porras, S. Melero, P.A. Garcia-Galavis, E. Morillo, and C. Maqueda. 2007. Comparison between organic and mineral fertilization for soil fertility levels, crop macronutrient concentrations, and yield. Agron. J. 99:973-983. doi:10.2134/ agronj2006.0168.

Hirzel, J., I. Matus, F. Novoa, and I. Walter. 2007. Effect of poultry litter on silage maize (Zea mays L.) production and nutrient uptake. Spanish J. Agric. Res. 5(1):102-109.

Hirzel, J., P. Undurraga, and I. Walter. 2010. Nitrogen mineralization and nutrients released in a volcanic soil amended with poultry manure. Chil. J. Agric. Res. 70(1):113121. doi:10.4067/S0718-58392010000100012.

Hirzel, J., F. Cerda, P. Millas, and A. France. 2012. Compost tea effects on production and extraction of nitrogen in ryegrass cultivated on soil amended with commercial compost. Compost Science \& Utilization 20(2):97-104. doi:10.1080/1065657X.2012.10737032.

Hirzel, J., S. Toloza, y F. Nova. 2016. Evolución a corto plazo de las propiedades químicas en dos suelos de la zona centro sur de Chile fertilizados con diferentes fuentes de calcio. Chilean J. Agric. Anim. Sci. 32(3):217-227. doi:10.4067/S0719-38902016005000006.

Hossain, N., M. Muhibbullah, K. Barkat, and M. Hossan. 2015. Relationship between soil salinity and physico-chemical properties of paddy field soils of Jhilwanja Union, Cox's Bazar, Bangladesh. J. Agric. Sci. 7:166-180. doi:10.5539/jas.v7n10p166.

Jiménez Becker, S., A. Ebrahimzadeh, B.M. Plaza Herrada, and M.T.Lao. 2010. Characterization of compost based on crop residues: changes in some chemical and physical properties of the soil after applying the compost as organic amendment. Commun. Soil Sci. Plant Anal. 41:696-708. doi:10.1080/00103620903563931.

Karanatsidis, G., and M. Berova. 2009. Effect of organic-N fertilizer on growth and some physiological parameters in pepper plants (Capsicum annum L.). Biotechnology \& Biotechnology Equipment 23:254-257.

Kirchmann, H., L. Bergström, T. Kätterer, L. Mattson, and S. Gesslein. 2007. Comparison of long-term organic and conventional croplivestock systems on a previously nutrientdepleted soil in Sweden. Agron. J. 99:960-972. doi:10.2134/agronj2006.0061.

Laboski, C.A.M., and J.A. Lamb. 2003. Changes in soil test phosphorus concentration after application of manure or fertilizer. Soil Sci. Soc. Am. J. 67:544-554. doi:10.2136/ sssaj2003.0544. 
Li, Z-F., R. Schulz, and T. Müller. 2009. Shortterm nitrogen availability from lupine seed meal as organic fertilizer is affected by seed quality at low temperatures. Biol. Agric. Hortic. 26:337-352. doi:10.1080/01448765.20 09.9755093.

Li,Z., R.Schulz, and T.Müller.2015. Mineralization of legume seed meals as organic fertilizers affected by their quality at low temperatures. Biol. Agric. Hortic. 31(2):91-107. doi:10.1080/ 01448765.2014.971871.

Lindsay, W.L., and W.A. Norvell. 1978. Development of a DTPA soil test for zinc, iron, manganese, and copper. Soil Sci. Soc. Am. J. 42:421-428.

Matus, F., E. Garrido, N. Sepúlveda, I. Cárcamo, M. Panichini, and E. Zagal. 2008. Relationship between extractable $\mathrm{Al}$ and organic $\mathrm{C}$ in volcanic soils of Chile. Geoderma 148:180188. doi:10.1016/j.geoderma.2008.10.004.

Miller, S.A., N. Patel, A. Muller, D.M. Edwards, and S.T. Solomona. 2006. A comparison of organic and conventional nutrient management protocols for young blueberry nursery stock. Acta Hortic. 715:427-432. doi:10.17660/ActaHortic.2006.715.64.

Mondini, C., M.L. Cayuela, T. Sinicco, M.A. Sánchez-Monedero, E. Bertolone, and L. Bardi. 2008. Soil application of meat and bone meal. Short-term effects on mineralization dynamics and soil biochemical and microbiological properties. Soil Biol. Biochem. 40:462-474. doi:10.1016/j.soilbio.2007.09.010.

Moreira, A., G.J. Sfredo, L.A.C. Moraes, and N.K. Fageria. 2015. Lime and cattle manure in soil fertility and soybean grain yield cultivated in tropical soil. Commun. Soil Sci. Plant Anal. 46:1157-1169. doi:10.1080/00103624.2015.103 3542.

Muñoz-Vega, P., H. Paillán, H. Serri, D. Donnay, C. Sanhueza, E. Merino, and J. Hirzel. 2016. Effects of organic fertilizers on the vegetative, nutritional, and productive parameters of blueberries 'Corona', 'Legacy', and 'Liberty'. Chil. J. Agric. Res. 76(2):201-212. doi:10.4067/ S0718-58392016000200010.

Pinochet, D., J. Mendoza, y A. Galvis. 2000. Potencial de mineralización de nitrógeno de un Hapludand con distintos manejos agrícolas. Cien. Investig. Agr. 27(2):97-106.

Retamales, J.B., and J.F. Hancock. 2012. Blueberries. p. 4-12. CABI, Cambridge, Massachusetts, USA
Sadzawka, A.R., M.A. Carrasco, R. Grez, M.L. Mora, H. Flores, y A. Neaman. 2006. Métodos de análisis recomendados para los suelos de Chile. Revisión 2006. Serie Actas INIA № 34. Instituto de Investigaciones Agropecuarias (INIA), Santiago, Chile.

Silva, D.J., L.H. Bassoi, M.G. da Rocha, A. O. da Silva, and M. Dall'IgnaDeon. 2016. Organic and nitrogen fertilization of soil under 'Syrah' grapevine: Effects on soil chemical properties and nitrate concentration. Rev. Bras. Cienc. Solo 40:e0150073. doi:10.1590/18069657rbcs20150073.

Tamada, T. 2004. Effects of nitrogen sources on growth and leaf nutrient concentrations of 'Tifblue' rabbiteye blueberry under water culture. Small Fruits Review 3(1-2):149-158. doi:10.1300/J301v03n01_15.

USDA. 2014. Keys to Soil Taxonomy. 12th. ed. 360 p. United States Department of Agriculture (USDA), Washington DC, USA.

USDA. 2017. National Organic Program Handbook: Guidance and Instructions for Accredited Certifying Agents and Certified Operations. Available at https://www. ams.usda.gov/sites/default/files/media/ Program\%20Handbk_TOC.pdf (Accessed 10 January 2018).

Wang, S.Y., C. Chen, W. Sciarappa, C.Y. Wang, and M.J. Camp. 2008. Fruit quality antioxidant capacity and flavonoid content of organically and conventionally grown blueberries. J. Agric. Food Chem. 56:5788-5794.

Wu, J., G. O'Donnell, and J.K. Syers. 1993. Microbial growth and sulfur immobilization following the incorporation of plant residues into soil. Soil Biol. Biochem. 25:1567-1573. doi:10.1016/0038-0717(93)90012-Z.

Yang, X., W. Ren, B. Sun, and S. Zhang. 2012. Effects of contrasting soil management regimes on total and labile soil organic carbon fractions in a loess soil in China. Geoderma 177-178:49-56. doi:10.1016/j. geoderma.2012.01.033.

Zhao, Q., C. Dong, X. Yang, X. Mei, W. Ran, Q. Shen, et al. 2011. Biocontrol of Fusarium wilt disease for Cucumis melo melon using bioorganic fertilizer. Appl. Soil Ecol. 47:67-75. doi:10.1016/j.apsoil.2010.09.010. 